\title{
THE ROLE OF RESERVISTS AND RESERVE ASSOCIATIONS TODAY
}

\author{
Lieutenant Colonel László UJHÁZY, PhD \\ ujhazy.laszlo@uni-nke.hu \\ Faculty of Military Sciences and Officer Training \\ National University of Public Service, Budapest, Hungary
}

\begin{abstract}
In this paper, the role of reservists is both discussed and analysed by the author. At the same time - based on the experience of NATO member states with a history and tradition longer than ours in this context - the author outlines the alternative options for possible participation by a reserve association in efforts aimed at supporting the volunteer reserve system and national defence as a whole in Hungary.
\end{abstract}

Keywords: all-volunteer force, civil-military relations, comprehensive approach, peace support operations, reservists, reservist associations, NATO, volunteer reserves

\section{Introduction}

Reservists are citizens of a country who combine a military career with a civilian career. They are not normally on active duty and their predominant function is to be available for military service when a state mobilises to deal with a crisis, the possibility of a crisis or when needed otherwise. Normally, reserve forces are not 
considered part of a permanent standing body of armed forces. The existence of reserve forces traditionally enables a country to downsize its peacetime military expenditure ${ }^{1}$ while preserving a force prepared for an armed conflict.

The modern interpretation of the term 'reservist' was initially used in the mid19th century. ${ }^{2}$ The system was first put to the test during the First World War or the 'Great War, as it was referred to at the time. Reservist employment ranged from mass at low rank level, to key command appointments on both sides, which had seen significant attrition by 1915 (Hajdu 2003). During the Second World War, this system was increasingly used on all sides. More recently, reservists had a crucial role during the Cold War period, as armed forces on both sides of the political divide were "mass armies" built on the principle of compulsory military service. Headcount was a consideration of crucial importance - reserve officers, for example, were needed mainly because armed forces were in need of sub-unit leaders/commanders.

\section{The modern reservist; bringing civilian specialisation to the military}

As the spectrum of warfare widens and operations other than war become more complex and prevalent, the use of reserves focuses more on their civilian knowledge skills and experience. The following words, attributed to former UN Secretary-General Dag Hammarskjöld ${ }^{3}$, can best describe the situation today: "Peacekeeping is not a job for soldiers, but only soldiers can do it" (Arbuckle 2007).

1 Using reservists can be extremely cost effective: in $200056 \%$ of US military capabilities were provided by reservists for no more than $8 \%$ of the military budget (The Reserve Components of the United States Armed Forces 2000).

2 In Hungary, the term 'compulsory military service' dates back to Act No. XXXIII on the Hungarian Army (draft), while the term 'reserve service member' dates back to the coming into force of Act No. XL of 1868 on Defence Forces. In the interwar period, Act No. II of 1939 on National Defence made a distinction between the service duties of normal reservists as opposed to those of supplementary reservists.

3 Dag Hjalmar Agne Carl Hammarskjöld (Jönköping, Sweden, 29 July 1905 - Ndola, Rhodesia and the Federation of Nyasaland [today Zambia], 18 September 1961) Swedish Nobel Laureate, $2^{\text {nd }}$ Secretary-General of the UN. Cold war prevailed throughout his entire term of office. 
The armed forces of the majority of developed countries have found their way out of this paradoxical situation partly by utilising more reservists - particularly volunteer reservists - because, by definition, a reservist is, to some extent a service member and, in some measure, a civilian, "twice a citizen" as Churchill referred to them (Pengelley 1995, p. 1). Today, the majority of NATO armed forces are composed mostly of all-volunteer forces with reduced manpower; in most cases, these armed forces need reserve officers not as platoon leaders or company commanders, but because of their professional background and skills as civilians. This is particularly true of peacekeeping, peace building and humanitarian relief (Peace Support Operations AJP-3.4.1. 2001).

It should be emphasised that until quite recently, security was an issue associated mostly with military and, to some extent, political considerations. This approach was evident within the Cold War bipolar context. In the post-Cold War era, peace and stability have become more vulnerable, and are facing an array of threats of increasingly higher levels of complexity. To that end, increasingly complex interpretations of security have emerged; economic, societal and environmental aspects have become the object of scrutiny (Buzan 2008). Evidence from military operations today seems to underscore that no effective crisis management can be carried out without a comprehensive approach capable of calling into play relevant political, civilian and military mechanisms. It is now clear that the methods associated with a traditional, purely military approach will not rise to the challenge posed by a wide array of circumstances threatening international security, despite the fact that those methods are considered important. Given that all crisis management methods available need to be exploited, involving reservists whose experience comes from the building and development of institutions or from having been part of the executive, the judiciary and law enforcement, can be a crucial element in their contribution to a process of stabilisation and reconstruction.

Against the backdrop of reduced military budgets, there is a tendency in most NATO member states for the reservists of all-volunteer armed forces to be regarded as "part-time" volunteers who serve in positions that do not have to be manned by "full-time" (regular) service members in peace-time (Poutvaara and Wagener 2007, p. 8). The armed forces do not train specialists for a significant proportion of these positions, so even the full-time, professional billets are 
filled by recruiting graduates from civilian educational institutions: physicians, psychologists, lawyers, media specialists, cultural anthropologists, civilian infrastructure specialists, interpreters etc.

While the armed forces are still in need of reservists who are known to have previously performed their military service as regular service members, it is a proven fact that post-Cold War era military operations increasingly require various civilian skills - to be utilised by individuals in uniform - which are not necessarily available to the regular forces today (Caforio 2003, p. 336). Unique opportunities for improving the relationship between the armed forces and society (Ben-Ari, Lomsky-Feder and Gazit 2008, pp. 593-614) - perceived as a growing need to be addressed during peace support operations - have equally been revealed. Reservists did not remain unaffected by changes in the security environment: "the importance of reserve forces is growing with the multiplication of military operations..." (NATO Handbook 2006, p. 98).

\section{How do reserve associations fit into the picture?}

Reserve associations are non-political and non-profit organisations. They are organised democratically and structured around a constitution. They are independent of the military hierarchy of the country. These associations represent reservists from all services and branches. Generally, their main functions are fostering the professional development of reservists, providing advice on reserve issues and supporting national defence:

1. Maintain the cohesion of reservists both physically and mentally, between calls-up for service.

From a purely military point of view, this is the most important aspect of all. Since reservists are on active duty for limited periods only, it is necessary to maintain their cohesion - through professional programmes, physically and mentally while they are in inactive status. Not only are volunteer reservists suitable for this, they expect it. It was in fact quite long ago, in the autumn of 2003, following our first 25-day preparatory period as volunteer reservists, that our battalion commander (who was unfamiliar with the current practice in NATO member 
states, which are more experienced than we are in this respect) had this to say in his farewell speech: "Having spent time together as volunteer reservists, we would all benefit from continuing our cooperation while in inactive status (...), which would save us the trouble of having to start from scratch next year." The reserve associations of our allies, who have a long-established, older tradition than we do when it comes to organizing reservist events, offer relevant programmes (shooting competitions, military patrol competitions, long-distance marches, language courses, lectures on security policy etc.) which, apart from providing assistance in maintaining the cohesion of reservists in inactive status, contribute to the improvement of reservists, both in terms of their physical condition and their understanding of the theoretical aspects of defence related issues.

2. International relations have proved helpful for reserve associations in their interoperability with the defence organisations of NATO member states.

The Interallied Confederation of Reserve Officers (CIOR) $)^{4}$, both in terms of its structure and the organisation's message, is a perfect framework for the whole spectrum of reserve officers ranging from second lieutenant to general. It puts cooperation in a proper international context for all reserve officers in terms of their mental as well as physical condition. CIOR's aim to provide opportunities in those areas is aptly reflected in its committee structure (Public Affairs, Language Academy, Civil Military Co-operation, Defence Attitudes and Security Issues, Legal Affairs, Military Competitions, Partnership for Peace and Outreach, Young Reserve Officers etc.) (http://www.cior.net/Organisation.aspx). Special mention should be made of the Interallied Confederation of Medical Reserve Officers (Confédération Interalliée des Officiers Médicaux de Réserve - CIOMR), CIOR's sister organisation focusing on a traditionally reservist area of specialisation: defence medicine ${ }^{5}$. Various other international reserve associations are also

4 In NATO, the significance and prestige of reservists and reserve officers, along with the organisations founded by reservists, are best illustrated by the fact that among a great number of civilian organisations, dedicated to advancing the cause of defence, the North Atlantic Treaty Organisation maintains a special relationship with only four parliamentary and social organisations. One of them is CIOR (NATO Handbook 2001, pp. 375-385, Military Decision on MC 248/1 - The Relationship between NATO and the Interallied Confederation of Reserve Officers - CIOR Resolution No. 248/1 of NATO's Military Committee on the NATO-CIOR relationship), North Atlantic Military Committee Secretary General, North Atlantic Treaty Organization, 27 March 1988).

5 On more information regarding the topic, see Ujházy (2010). 
in existence ${ }^{6}$. There is a separate association for non-commissioned officers as well?.

3. They constitute a connecting link between the armed forces and society.

At the beginning of the 3rd millennium, the demobilisation of the last conscript service members on 3 November 2004 marked a new era across the whole spectrum of Hungary's defence system, i.e. in terms of the correlation between the armed forces and society (Tibori, Molnár and Gyimesi 2005, pp. 57-72). This put an end to a 136 year period, during which the relationship between the armed forces and society was based on some kind of dialogue and civilian control. While, as a result of ongoing political changes, the armed forces became considerably more open to the external world, the disappearance of the conscript system led to a situation in which the armed forces became a separate caste and a new isolation was underway within society ${ }^{8}$. It goes without saying that in this situation, the role of reservists and their associations are gaining a special significance. Today, the link connecting the armed forces and society is partly met by reservists and their associations, as they have the potential to resonate with those segments of society which the majority of messages generated by official politics will not. It has been proven by experience at an international level that reserve associations can even undertake the task of participating in the work of professional forums that help cooperation between employers and the armed forces (Roll 2014).

4. They constitute a connecting link between regular and reserve forces.

The status of volunteer reservists is a unique one. In the words of Winston Churchill "a reservist is twice the citizen" given the fact that notwithstanding his military duties, he is, fundamentally, a civilian. My own experience seems to underline the fact that when it comes to an individual's motivation and commitment, the focus is on "volunteer" not on "reservist". Put differently, there are similarities between reservists and the other volunteer service members - the regulars - who also serve in the armed forces. Personally, I am of the view that "part-time volunteer" is a more accurate definition to describe their status. They could be likened to people

6 On more information regarding the topic, see Ujházy (2010).

7 On more information regarding the topic, see Ujházy (2010).

8 This trend is a cause for concern in other countries as well, see Schafer (2017, pp. 2-18). 
who love football but never become professional football players. However, there is a significant difference between their motivation, viewpoint, conduct, social interactions and those of service members in the other category. Therefore, just as important as their role as a connecting link is to constitute another link: one between the above-mentioned categories of service members (McDonald 1999, p. 8).

The help that reserve associations provide in looking at the reservist issues and the relationship between the armed forces and society - particularly from the point of view of decision-makers - is a crucial one.

5. They provide assistance in the recruitment of reservists.

Recruitment, whether it be regular service members or volunteer reservists, is a key issue for the all-volunteer forces. Again, it needs to be emphasised that because of their deep social roots, reserve associations are capable of resonating with those segments of society which the majority of messages generated by official politics either will not reach, or just a fraction of those messages will find their way to. Based on experience at an international level, reserve associations do have a role to play in the recruitment of all categories of service members, particularly volunteer reservists.

6. They increase awareness in the society of the significance of defence-related issues.

In the post-Cold War era, while "awareness of the significance of defence" was on the wane across the whole spectrum of NATO, these organisations helped maintain vigilance in all sections of society. Representatives of these organisations hold the view that reservists, given their unique relationships with and within society as such, are the best diplomats advocating the values of the armed forces. However, this is a reciprocal process: reservists can offer specialised civilian expertise to the armed forces and, at the same time, act as intermediaries making sure that the armed forces are receptive to the messages rooted in the mentality of the civilian population (NATO Handbook 2006). We can, therefore, claim with certainty that in an era when the armed forces are developing an increasingly professional profile, reserve associations have an unprecedented, crucial role along with the responsibility arising from that role (The Use of Reservists within NATO). 
7. They act as advocates promoting the interests of reservists.

Problems associated with service members in this category are, in many ways, different from those affecting regular or even retired service members; therefore, a great number of countries with a tradition longer than ours in tackling such issues have assigned the key task of promoting the interests of reservists to their reserve associations?.

\section{Conclusions}

I believe that these are times when the existence of a reserve association in Hungary is of particular importance in the same way as reservists (Szűcs n.d.) are vital for the armed forces or volunteer reservists are vital for the volunteer reserve forces. I would even venture to say that no volunteer reserve system can survive without a reserve association to support it. As true as it is that the Hungarian Defence Forces lack crucial capabilities without a volunteer reserve system, the volunteer reserve system will also lack capabilities without organisational support stemming from society itself, provided by a reserve association.

\section{References}

Arbuckle, J., 2007. No job for a soldier? NATO Review. [online] Available from: https:// www.nato.int/docu/review/2007/issue3/english/analysis1.html [Accessed 21 Oct 2017].

Act No. XXXIII of 1848 on the Hungarian Army (Draft)

Ben-Ari, E., Lomsky-Feder, E. and Gazit, N., 2008. Reserve Soldiers as Transmigrants: Moving between the Civilian and Military Worlds. Armed Forces \& Society 34(4), 593-614.

Buzan, B., 2008. People, States and Fear: An Agenda for International Security Studies in the Post-Cold War Era. Hertfordshire, Harvester Wheatsheaf, 20.

Caforio, G. (ed.), 2003. Handbook of the Sociology of the Military. Kluwer Academic/ Plenum Publisher.

9 Based on CIOR guidelines and recommendations approved in 1996 regarding reserve (officers') associations, see Ujházy (2011, pp. 114-115). 
CIOR homepage. [online] Available from: http://www.cior.net/Organisation.aspx [Accessed 28 Dec 2017].

Hajdu, T., 2003. A hadkötelezettség és a haza védelmének eszménye a soknemzetiségü Monarchiában (Compulsory Military Service and the Ideal of National Defence in the Multi-ethnic Austro-Hungarian Empire). Hadtörténelmi Közlemények 116(1), $32-39$.

http://www.cior.net/Organisation.aspx [Accessed 21 Oct 2017].

Jobbagy, Z., 2006. Effects-Based Operations and the Age of Complexity: A Critical Reflection. Militaire Spectator 175(5), 235-238.

Lataste, P., 2002. L'Union Nationale des Officiers de Réserve (UNOR) - France (National Union of Reserve Officers [UNOR] - France). RAA Info, 5, 10-11 March, 2002. [online] Available from: https://www.act.nato.int/images/stories/structure/reserve/ newsletter_2002-03.pdf [Accessed 27 Feb 2018].

McDonald, C., 1999. The Canadian Armed Forces: The Role of the Reserves. Library of Parliament Political and Social Affairs Division, Ottawa.

Military Decision on MC 248/1 - The Relationship between NATO and the Interallied Confederation of Reserve Officers - CIOR, North Atlantic Military Committee Secretary General, North Atlantic Treaty Organization, 27 March 1988.

NATO Handbook. 2006, Public Diplomacy Division, Brussels, 98.

Peace Support Operations AJP-3.4.1. 2001.

Pengelley, R., 1995. Twice a Citizen. International Defence Review 28(8), 1.

Poutvaara, P. and Wagener, A., 2007. Conscription: economic costs and political allure. The Economics of Peace and Security Journal 2(1), 8.

Roll, R., 2014. Study of Employer Support. [online] Available from: http://www.cior.net/ News/2014/Study-of-Employer-Support.aspx [Accessed 28 Dec 2017].

Schafer, A., 2017. Generations of War: The Rise of the Warrior Caste and the All-Volunteer Force. Center for a New American Security, Washington, DC.

Szűcs, L., Nincsen hadsereg tartalék nélkül (No Army Can Exist without Reservists). [online] Available from: http://www.honvedelem.hu/news/22308/nincsen-hadseregtartalek-nelkul [Accessed 7 Oct 2017].

The Reserve Components of the United States Armed Forces. December 2000, Handbook by the Office of the Assistant Secretary of Defense for Reserve Affairs

The Use of Reservists within NATO. Remarks by General Harald Kujat Chairman of the NATO Military Committee, [online] Available from: https:/www.nato.int/ims/2003/ s030723e.htm [Accessed 8 Oct 2017].

Tibori, T., Molnár, F. and Gyimesi, Gy., 2005. Az önkéntes haderő társadalmi háttere társadalomtudományi helyzetkép és prognózis (The Social Background to Reserve Forces - A Sociological Snapshot and Prognosis). Hadtudományi Tájékoztató 14(Special Issue), 57-72. 
Ujházy, L., 2010. A nemzetközi tartalékos szövetségekről (On International Reserve Associations). Hadtudomány 30(4), 89-101.

Ujházy, L., 2010. A NATO Tartalékos Egészségügyi Tisztek Szövetsége (The Interallied Confederation of Medical Reserve Officers). Honvédorvos 62(1-2), 66-72.

Ujházy,L., 2010. AzEurópai Tartalékos Tiszthelyettes Szövetség(The European Association of Reserve Non Commissioned Officers). Honvéd Altiszti Folyóirat 22(3), 21-22.

Ujházy, L., 2011. Tartalékos szövetségek a NATO-ban (Reserve Associations in NATO). PhD Dissertation, Zrínyi Miklós National Defence University, Budapest. 